\title{
Density dependence of growth and production in a Wadden Sea population of the cockle Cerastoderma edule
}

\author{
J. J. Beukema*, R. Dekker \\ Royal Netherlands Institute for Sea Research, PO Box 59, 1790AB Den Burg, Texel, The Netherlands
}

\begin{abstract}
In suspension-feeding bivalves, growth rates generally remain at a high level over a broad range of numerical densities. However, data series on growth and production that cover a wide density range in a natural marine benthic system appear to be scarce. A long-term monitoring study (1973-2013) of zoobenthos on tidal flats in the western Wadden Sea yielded twiceannual data on numbers and weights of (among others) cockles Cerastoderma edule, allowing estimates of their annual and cohort production by the weight-increment summation method. In nearly all years, cockle densities did not exceed a few $100 \mathrm{~s} \mathrm{~m}^{-2}$, and their individual weight increments showed no significant relationship with density. Only the appearance of one exceptionally strong year class in 2011 caused higher densities over an extensive area for $>1$ yr. Growth rates in all cockles were significantly reduced in the second growing season of this strong cohort, when their densities amounted to $>500 \mathrm{~m}^{-2}$. Seasonal and annual survival did not show a significant relationship with density. As a consequence of the reduction in growth of its members, production of the single strong cohort was substantially less than expected on the basis of its initial abundance. In all smaller cohorts, the positive relationship between recruit numbers and cohort production was close to linear. However, when the higher density of the one strong year class was included, an inverse-U shaped line would better characterize this relationship. Appearances of very strong bivalve cohorts are rare events in the Wadden Sea: bivalve stocks on the tidal flats usually appear to be far below the carrying capacity of the area for suspension-feeding animals.
\end{abstract}

KEY WORDS: Density dependence - Seasonal weight growth · Annual production · Carrying capacity $\cdot$ Wadden Sea

\section{INTRODUCTION}

For a better understanding of the functioning of an ecosystem, knowledge of underlying processes at the population level of the constituting species is indispensable. For a proper interpretation of changes in ecosystem functions, the population dynamics of all dominant species should be followed and the relationships between their numerical densities and functions (such as consumption and production) should be revealed.

Bivalves generally play a key role in the functioning of coastal marine ecosystems. Variability in their rates of growth and resulting production and biomass might be related to variation in the availability of food. However, in the majority of bivalves that are filter feeders, competition for food appears to be less fierce than in deposit feeders, as the former are less dependent on food produced in their immediate vicinity, allowing them to live in dense aggregations such as mussel beds and cockle banks (Levinton 1972, Beukema et al. 1983). As such extensive and dense beds of filter feeders are usually supplied with plentiful food delivered by water movements from the vast surrounding area, their secondary production may even exceed local primary production (Loo 
\& Rosenberg 1996). Such situations frequently occur in intertidal areas bordering productive seas. Withinspecies competition for food may then be weak over a wide range of numerical densities.

Experimentally, Kamermans et al. (1992) showed that intra-specific competition for food (resulting in negatively density-dependent growth) was simultaneously present in the deposit-feeding bivalve Macoma balthica, but absent in the suspension-feeding Cerastoderma edule. Nevertheless, some cases have been reported of reduced growth rates at extremely high numerical densities in typical suspension feeders: for instance, in a natural cockle $C$. edule population in the Danish Wadden Sea (Jensen 1992, 1993) and in Katelysia species in a manipulated population in Australia (Peterson \& Black 1993). As far as we are aware, there are no reports on bivalve growth rates that were consistently recorded at a wide range of non-manipulated densities in a natural environment. By manipulating densities in the field, de Montaudouin \& Bachelet (1996) found cockle growth rates to be depressed only at extremely high densities of $2000 \mathrm{~m}^{-2}$. A long-term (started in the early 1970s) monitoring program of macrozoobenthos in the western part of the Dutch Wadden Sea yielded a 40-yr data series on (among others) numbers and weights of cockles that enabled us to study relationships between density and growth as well as production in this species.

From estimation using the weight-increment summation method (Van der Meer et al. 2005), it is immediately clear that production magnitude of a population is determined by its numerical density and weight change per individual member. If rates of growth and mortality were not density dependent, mean production per individual recruited to a population would be independent on recruit numbers and production would increase linearly with recruit density. Such simple linear relationships between recruit numbers and cohort production, suggesting nonexistence of density-dependent growth and mortality, have been observed over wide density ranges in some natural bivalve populations, for instance in Macoma balthica (Van der Meer et al. 2001, Dekker \& Beukema 2007), C. edule (Beukema \& Dekker 2006), Mytilus edulis (Beukema \& Dekker 2007), and Ensis directus (Dekker \& Beukema 2012). However, it is inconceivable that a linear increase of production with recruit density could continue at extremely high densities. Nevertheless, examples of leveling off (or even declines) of production at high numbers appear to be rare for natural conditions, though this phenomenon is well known in aquaculture, where optimal rather than maximal stocking densities are generally applied.

In 2011 (>40 yr after the start of our annual monitoring efforts), extremely high recruitment occurred in the $C$. edule population, with $>1000$ ind. $\mathrm{m}^{-2}$ over a vast intertidal-flat area of $>10 \mathrm{~km}^{2}$, including several of our sampling sites. The appearance of this strong cohort gave us an opportunity to assess growth and production rates at high numerical densities and to investigate whether rates of growth and production declined at high densities. Our hypotheses are that at very high cockle densities: (1) growth rate is reduced and (2) production rate is substantially lower than expected from an extrapolation of the linear relationship numerical density as described earlier for cockles in Beukema \& Dekker (2006).

\section{MATERIALS AND METHODS}

\section{Study area}

The data were obtained as part of a long-term (started around 1970) program involving twiceannual sampling of macrozoobenthos at 15 permanent sampling stations located on Balgzand, a $50 \mathrm{~km}^{2}$ tidalflat area in the westernmost part of the Wadden Sea (at $\sim 53^{\circ} \mathrm{N}, 5^{\circ} \mathrm{E}$ ). Further details on the sampling area, stations, and methods can be found in Beukema \& Cadée (1997). Out of these 15 stations, 6 in the central part of Balgzand (Transects 4, 5, 8, 9, 10, and 11, Fig. 1) were chosen for the present study of growth rates of Cerastoderma edule. This part of Balgzand covered approximately one-third of the total Balgzand tidal-flat area of $50 \mathrm{~km}^{2}$. In the part of Balgzand to the north of this area, cockle recruitment failed in nearly all years, probably due to adverse environmental conditions (exposure to strong currents and wave action, resulting in unstable and coarse sediments; see Fig. 7 of Beukema \& Dekker 2005). South of the selected area, cockle numbers were mostly lower and growth rates were invariably lower than in the selected area, probably due to higher intertidal levels (shorter daily immersion times) and muddy sediments. In most years, cockle growth rates hardly differed between the 6 sites within the study area.

\section{Cockle sampling}

Along each of the $1-\mathrm{km}$ transects, 50 cores were taken twice-annually at equal intervals to a depth 
of approximately $30 \mathrm{~cm}$. In March, when cores of nearly $0.02 \mathrm{~m}^{2}$ were used, the sampled area per transect covered a total of $0.95 \mathrm{~m}^{2}$. In August, using cores of nearly $0.01 \mathrm{~m}^{2}, 0.45 \mathrm{~m}^{2}$ were covered per transect. Cockles were sorted from the sieved (1$\mathrm{mm}$ mesh size) samples, assigned to age classes (year of birth), counted (numerical density was expressed in no. $\mathrm{m}^{-2}$ ), sorted to shell length classes (mm), their soft parts dried to constant weight, weighed per $\mathrm{mm}$ length class, incinerated, and again weighed to obtain by subtraction ash-free dry mass (AFDM). Age determination in Balgzand cockles was usually easy and precise (Beukema 1989).
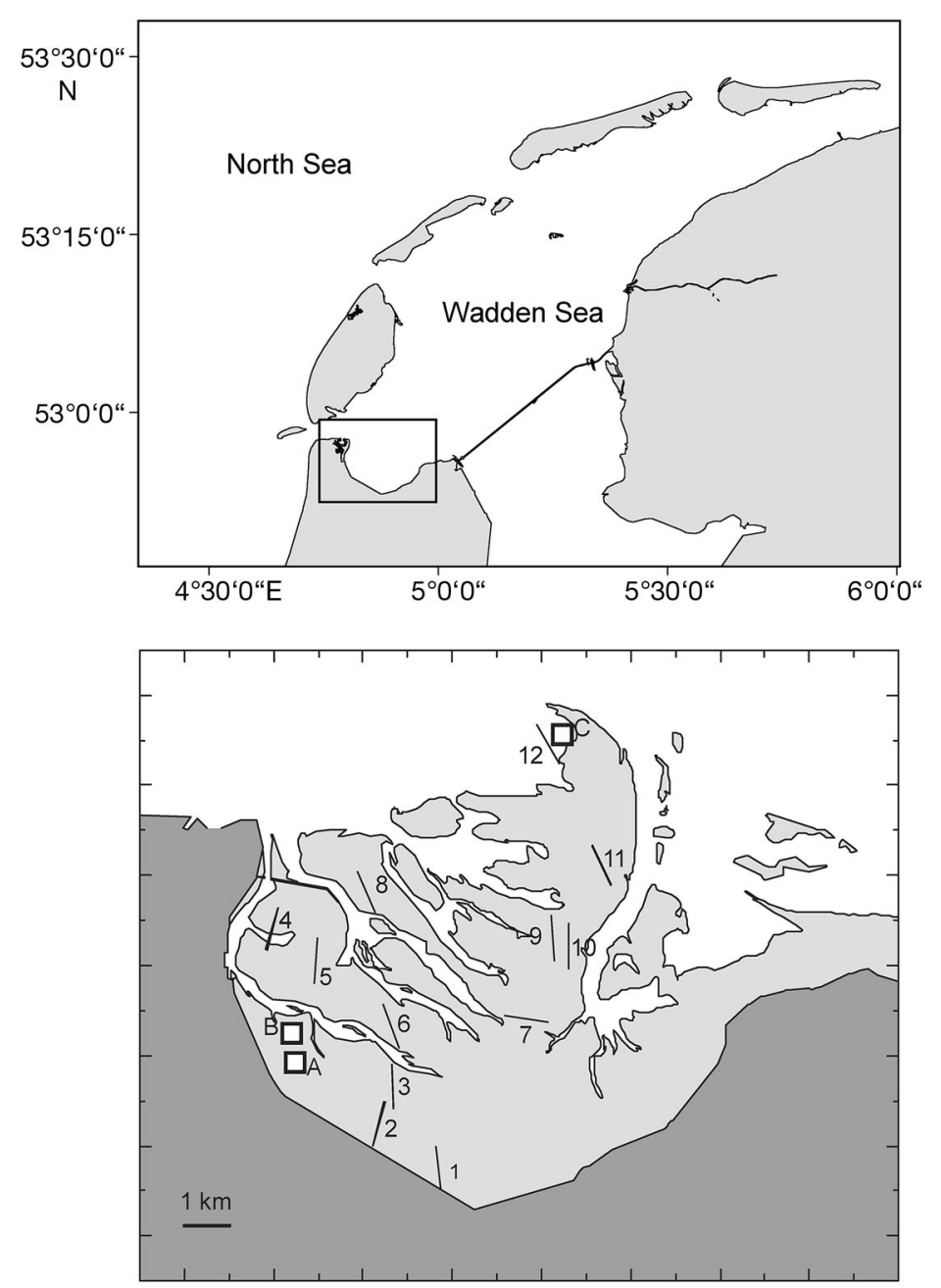

Fig. 1. Maps of (top) the westernmost part of the Wadden Sea and (bottom) the Balgzand tidal-flat area. The permanent sampling sites are indicated: 12 transects (numbered 1-12) and 3 squares (A, B, and C). Cockle growth rates were studied in detail at the 6 transects numbered 4, 5, 8, 9, 10, and 11 in the central part of Balgzand

\section{Estimates of growth}

Seasonal growth was defined as the weight increment per individual belonging to a certain year class between March and August and was expressed in g AFDM ind. ${ }^{-1}$. As the first growing season in the life of cockles does not end in or around August (as do growing seasons in older cockles; Beukema \& Dekker 2006), for 1st-year cockles we used the mean weight per individual reached in March (at an age of approximately $10 \mathrm{mo}$ ) as a proxy for growth in the first year.

For estimates of growth, we used data from a sampling site only if the year class to be studied was represented by at least 10 individuals in the samples taken at the start as well as at the end of the growing season. For an estimate of mean growth in a particular year, such numbers should be available at 4 or more of the 6 sites. In practice, it was 6 sites in more than half of the years, as successful year classes tend to arise simultaneously over large areas (Beukema et al. 2001). During the 1973-2013 period, sufficient numbers of cockles were present for precise growth estimates in 15 year classes for the 1st growing season, 14 year classes for the 2nd growing season, and 9 year classes for the 3rd growing season.

\section{Estimates of production}

Production (P) was estimated as explained in Beukema \& Dekker (2006). In short, the weightincrement summation method was followed, summing the weight increments $(\mathrm{d} W)$ of all members (mean of no. $\mathrm{m}^{-2}$ at start and end of period) of the year class at a site. Annual production (March to March) production was estimated at all 15 sites, completing up to 2013 the data for the 1973-2003 period presented in Beukema \& Dekker (2006). Separate production estimates were made for the 14 cohorts in which we studied growth rates in their 2 nd growing season in the central part of Balgzand: both their lifetime production and the part of it accomplished in their 2nd growing season. Note that estimates of growing-season production in adult cockles are invariably higher than annual production. This is a consequence of seasonal weight loss in individual adult cockles in the autumn/winter periods, resulting in negative values for production between late summer and late winter. Thus, net annual production is the sum of March-August and August-March production estimates. 
All production values refer to somatic production. For practical reasons, production in the spat stage (cockles <10 mo old) was not assessed. In the present paper, we define 10-mo-olds (in the first March of their life) as recruits.

\section{Data adjustment}

Raw data of weight increments can be used as such for estimates of production, but should not be applied for a proper comparison of growth rates between years. For the latter, the individuals involved should be of a similar size at the start of the growing season. Within the same population, the smaller-thanaverage individuals grow more rapidly in length (the catch-up phenomenon; see Lammens 1967) but more slowly in weight (own unpubl. obs.) than the largerthan-average ones. Because initial mean weights $W_{\mathrm{i}}$ of the cockles at the start of the growing seasons differed substantially between cohorts (and thus between years), we had to adjust the raw data of weight increments $(\mathrm{d} W)$ in the 2nd growing season for each growing year separately. The increment values were adjusted in such a way as to apply to an individual with a standard weight of $0.023 \mathrm{~g}$ AFDM, which was close to the long-term average of $W_{\mathrm{i}}$ in the central part of Balgzand. Adjusted growth estimates were calculated as $\mathrm{d} W_{\text {adj }}=\mathrm{d} W+1.75\left(0.023-W_{\mathrm{i}}\right)$. This formula was obtained from a detailed data set of length and weight measurements in a high number of individuals of 1 cohort, in which individual growth histories were read from annual marks on their shells. We did not adjust the weight increment data for the 3rd growing season, because the differences between means of raw and adjusted data proved to be small for these older cockles.

\section{RESULTS}

\section{Growth rates}

In cockles of $>10$ mo old, weights of the soft parts showed a consistent seasonal pattern, with gains in the spring/summer half-year and losses in the remainder of the year (Fig. 2). They reached their maximal individual weights usually in August and minimal weights in March (as reported earlier in Beukema \& Dekker 2006). In cockles of $>10$ mo old, the March-August periods were seasons of weight increases and the August-March periods were characterized by weight losses.

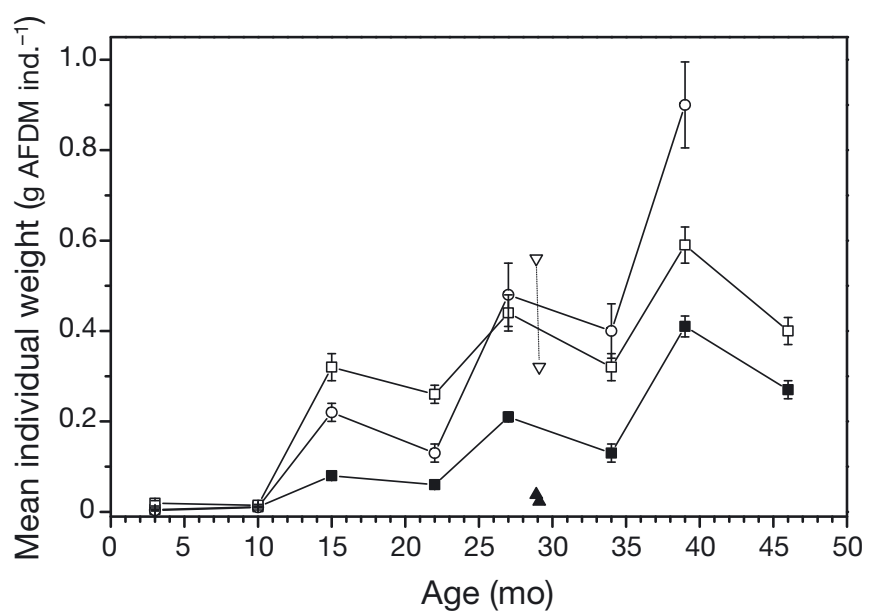

Fig. 2. Changes in mean $( \pm 1 \mathrm{SE}, \mathrm{n}=6)$ weight of soft parts (expressed in $g$ ash-free dry mass [AFDM] ind.$^{-1}$ ) in the course of life of cockles Cerastoderma edule belonging to 3 strong cohorts at 6 sites on Balgzand (see Fig. 1). August estimates are plotted at ages of 3, 15, 27, and $39 \mathrm{mo}$; March estimates are plotted at 10, 22, 34, and 46 mo. Open squares: born in 1979; open circles: born in 1987; solid squares: born in 2011. Note the small SE values for the mean weights observed in the 2011 cohort. The triangular points added at 29 mo are from Jensen (1993) for a weak (open points) and a very strong (solid points) year class of cockles at 2 sampling stations in the Danish Wadden Sea

We studied rates of weight increase between March and August in 1-yr-old (2nd growing season) and $\sim 2$-yr-old (3rd growing season) cockles at 6 sites on the central part of Balgzand and in a limited number of (relatively strong) cohorts (14 for 1-yr-olds and 9 for 2 -yr-olds). The estimated seasonal weight increments varied strongly from year to year (Fig. 3). Raw and adjusted estimates of mean weight increment were only slightly different (compare solid and open points in Fig. 3A), though the year-to-year variation was somewhat lower in the adjusted than in the raw data. Growth rates showed a similar long-term pattern in the 1-yr-old (Fig. 3A) and 2-yr-old cockles (Fig. 3B): relatively high growth rates were observed particularly in a few years in the 1990s (or late 1980s), intermediate growth rates were observed in most of the years of observation in the 1970s, 1980s and 2000s, and very low growth rates were observed in 2012.

In 2012, total cockle numbers at the start of the growing season were exceptionally high (see the rightmost points in Fig. 4B,C). Note that the standard errors for the means in the year 2012 were very small, indicating that growth rates declined at all sites in these years with high cockle abundance. 


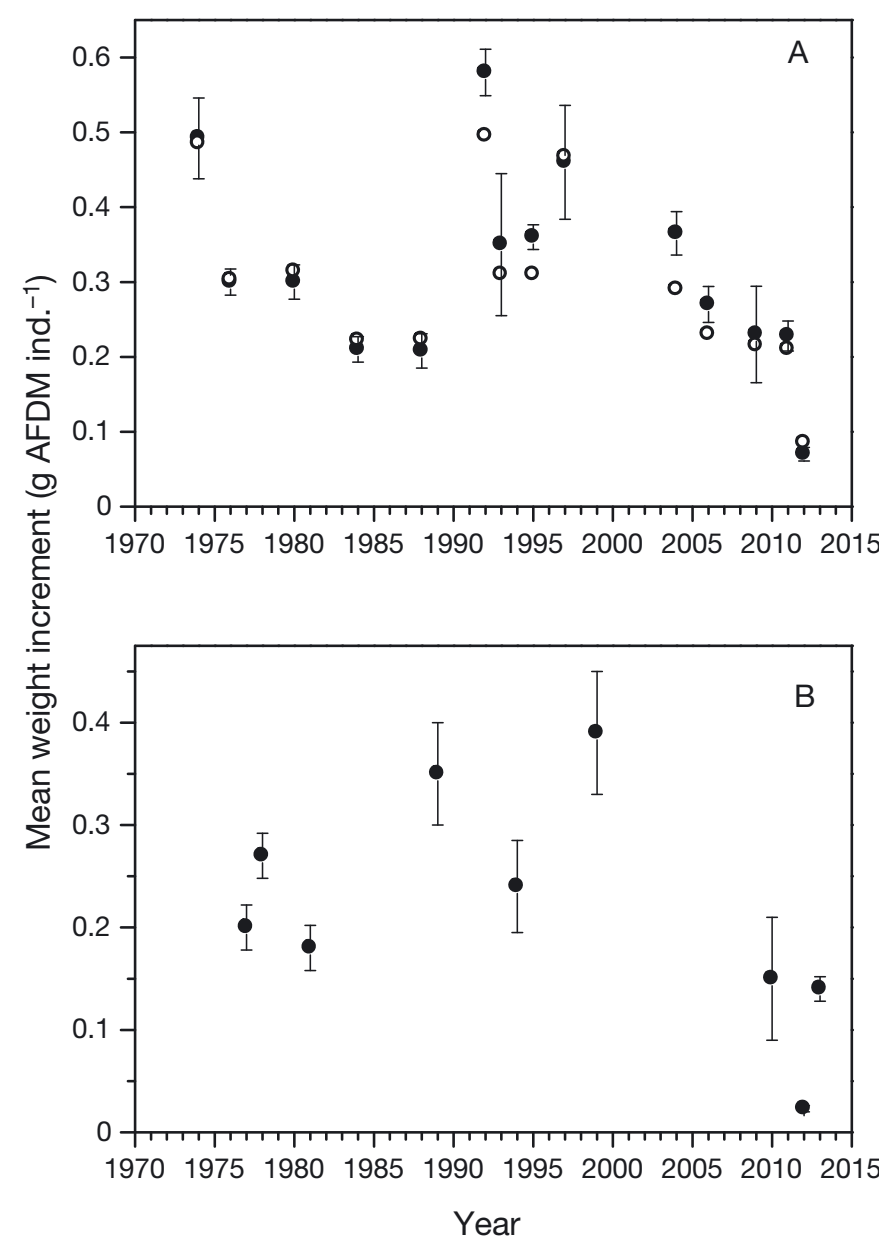

Fig. 3. Changes over the 40-yr period (1973-2013) in mean growth rates of cockle Cerastoderma edule individuals on Balgzand (means of observations at 6 sites). Cockle growth was measured as mean weight increment per individual between March and August and is expressed in $g$ ash-free dry mass (AFDM) \pm 1 SE. Only years with sufficient observations are included. (A) Growth in the 2nd growing season ( 1-yr-old cockles) as raw data (solid points) and data adjusted to show growth in a cockle of standard initial weight (open points). The point for the growing year 2012 refers to the strong cohort born in 2011. (B) Growth in the 3rd growing season of the life of cockles (raw data). The 2011 cohort is represented by the point for 2013, but in that year this cohort was no longer exceptionally abundant, nor was the total cockle population

Seasonal weight increments were on average higher at low than at high numerical densities (Fig. 4). A high proportion of the between-year differences were statistically significant, as can easily be judged from the standard errors, being frequently several times smaller than these differences. Cockles of all ages (Fig. 4) showed an inverse relationship between density and growth. Growth in the first growing sea- son was assessed only by the end of their first year of life, at an age of approximately 10 mo, just before the start of their 2nd growing season. The cockle recruits were mostly heavier when they were members of a weak than a strong year class (Fig. 4A), though this relationship was hardly significant. In their 2 nd and 3rd growing seasons, cockles gained on average more weight in years with low than with high numerical densities (Fig. 4B,C). However, the statistical significance of the declines in growth with increasing density fully originated from the low growth rates observed at the highest total density, occurring in 2012. When data from this year were left out, the relationship between density and seasonal weight increment became non-significant (broken lines in Figs. 4B,C).

Growth reduction in 2012 not only was statistically significant, but was also substantial. For the 2nd growing season, the weight increments in the 2012 growing season amounted to only 21 and $27 \%$ (raw and adjusted data, respectively) of the average of weight increments in the 13 other years. For cockles in their 3rd growing season (comparison with 8 other years) this proportion was even as low as $10 \%$.

\section{Production rates}

Strong year classes had a higher production than small cohorts. Peaks in the number of recruits (Fig. 5A) coincided with peaks in lifetime cohort production (Fig. 5B). Cockle cohorts produce high amounts especially in their 2nd growing season, when seasonal weight gain per individual is maximal (Fig. 4B) and numbers are still high. In the 2nd year of their life, they produced on average more than twice the total amount they produced in all subsequent years of their life combined. This explains why peaks in annual production (the summed production of all >10-mo-old cockles of all cohorts present in that year) occurred just 1 yr later than the years in which a strong year class was born (compare Fig. 5C with Fig. 5B).

Despite its exceptionally high number of recruits (Fig. 5A), the lifetime production of the 2011 year class was not really exceptional (Fig. 5B) and the annual cockle production in 2012 (that was made up of $>95 \%$ of contributions by this cohort) was far from the highest recorded on Balgzand (Fig. 5C).

The lifetime production of cockle cohorts increased more or less linearly with their density in the recruit stage (at an age of approximately $10 \mathrm{mo}$ ) over a wide range of initial densities from 0 to $\sim 400 \mathrm{~m}^{-2}$ (broken 
line in Fig. 6A). In the one strong cohort (born in 2011) with a much higher initial density $\left(\sim 1000 \mathrm{~m}^{-2}\right.$ in the central part of Balgzand), cockle production was only about one-third (34\%) of the value to be
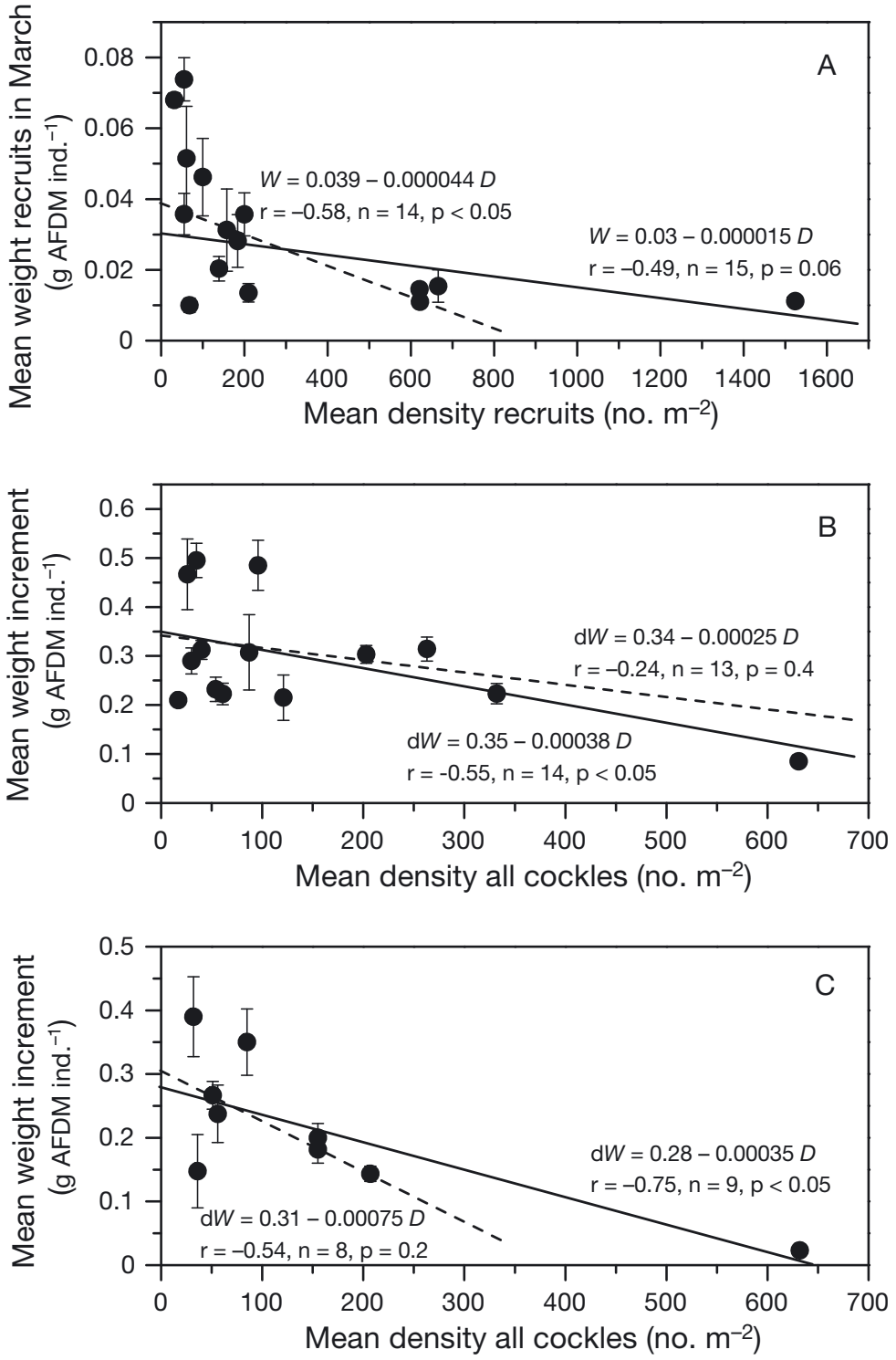

Fig. 4. Relationships between numerical densities of cockles Cerastoderma edule $\left(D ;\right.$ no. $\left.\mathrm{m}^{-2}\right)$ and their mean individual growth rates. Data are means obtained at 6 sites in the central part of Balgzand; 1 point for each year with sufficient data available. Solid lines refer to the entire data sets; dashed lines exclude the strong cohort of 2011. (A) Mean individual weights $(W)$ of cockle recruits $( \pm 1 \mathrm{SE}, \mathrm{n}=6$ in most cases) as reached in March at an age of $\sim 10$ mo, plotted against mean densities of cockle recruits (<10 mo old) during the preceding August-March periods. (B) Mean individual (adjusted) weight increments ( $\mathrm{d} W, \pm 1 \mathrm{SE}, \mathrm{n}=6$ in most cases) in the 2nd growing season at a range of mean densities of cockles of at least 10 mo old (means of assessments in March and August). (C) Mean individual weight increments ( $\mathrm{d} W, \pm 1 \mathrm{SE}, \mathrm{n}=6$ in most cases) in the $3 \mathrm{rd}$ growing season at a range of mean densities of cockles of at least 10 mo old (means of assessments in March and August) expected if this linear relationship had continued at high densities. Thus, the full-range relationship between initial cohort strength and its production could be described more satisfactorily by either a 2ndorder polynomial (solid line in Fig. 6A) or a saturation curve with a plateau at a maximal cohort production of around $80 \mathrm{~g} \mathrm{AFDM} \mathrm{m}^{-2}$ in this part of Balgzand. The above reduction to $34 \%$ roughly corresponded to that found in the 2nd-season individual weight increment in the largest cohort: from an average of $\sim 0.3 \mathrm{~g}$ for the 13 smaller cohorts to $\sim 0.1 \mathrm{~g}$ for the 1 large cohort (see Fig. 4B).

Reduction of cohort production by negative density dependence of seasonal growth was certainly present at an initial high density of $\sim 1000 \mathrm{~m}^{-2}$. At low densities (a few 100s $\mathrm{m}^{-2}$ ), linear and quadratic fits were similar and these 2 fits described the dependence of production on initial numbers about equally well (Fig. 6A). However, the exact density at which negative density dependence started cannot be inferred from Fig. 6A.

Annual production values of cockle populations (Fig. 7) showed a relationship with numerical density similar to that observed for cohorts (Fig. 6A). This similarity was to be expected, because the production of a cockle cohort is largely realized in the year including its 2nd growing season. Again, the relationship for all data points could satisfactorily be described by a 2nd-order polynomial or a line leveling off at a maximal annual production of between 20 and $30 \mathrm{~g}$ AFDM m${ }^{-2} \mathrm{yr}^{-1}$ for the entire Balgzand. A straight line offered a good fit when production at the highest density was excluded. Note that both of the relationships depicted in Fig. 7 were highly significant. The annual production at the highest density was less than half (41\%) of the value obtained by extrapolation from the linear relationship.

The slope of the dashed line in Fig. 6A would indicate a lifetime production per recruit of approximately $0.22 \mathrm{~g}$ AFDM in all cohorts, except the largest one. The between-cohort variability in this value was not negligible, ranging from $\sim 0.1$ to $\sim 0.5 \mathrm{~g} \mathrm{AFDM} \mathrm{ind.}{ }^{-1}$ (Fig. $6 B)$. Up to initial densities of $\sim 400 \mathrm{~m}^{-2}$, these values did not consistently differ between weak and strong cohorts (the relationship depicted by the broken line in Fig. 6B was non-significant). Inclusion of the strongest cohort (full line in Fig. 6B) resulted in a signifi- 

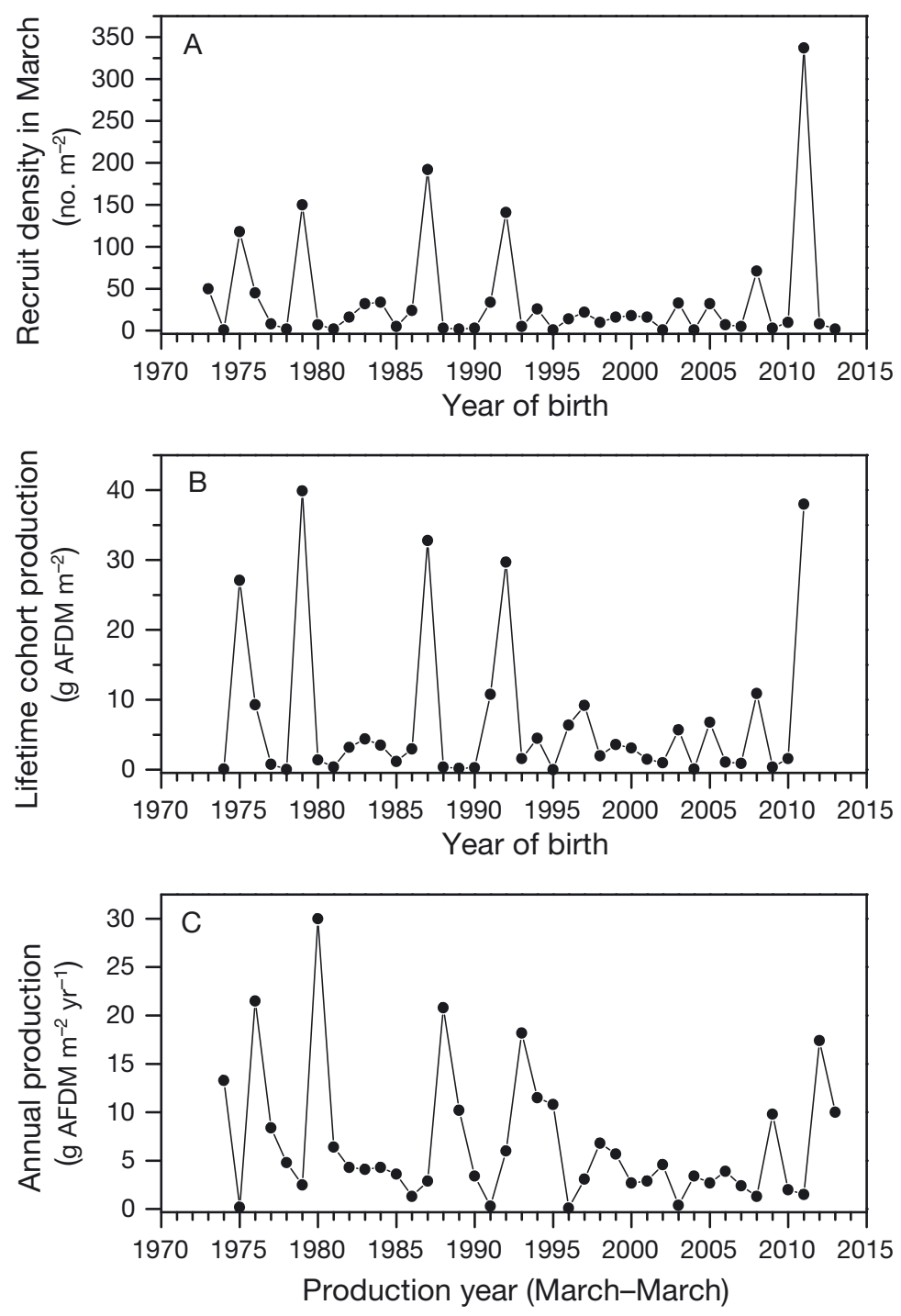

Fig. 5. Changes over a 40-yr period (1973-2013) of recruitment and production in the Cerastoderma edule cockle population on Balgzand (means of all 15 sampling sites). (A) Annual recruitment (no. $\mathrm{m}^{-2}$ ) as assessed in March of each year, at an age of 10 mo (the earlier year of birth indicated). (B) Net somatic lifetime production ( $\mathrm{g}$ AFDM m $\mathrm{m}^{-2}$ ) of these cohorts as accomplished after the age of 10 mo (estimates for most recent cohorts incomplete and therefore omitted). (C) Net somatic annual production of all $>10$-mo-old cockles present in the indicated year, expressed in $\mathrm{g}$ AFDM m ${ }^{-2} \mathrm{yr}^{-1}$

cantly negative relationship between cohort strength and production per recruit. In this analysis, 5 cohorts (open points) were left out of consideration, because the values of their production and production per recruit were seriously reduced by a heavy mortality early in their life as a consequence of a severe winter. They were not excluded from Fig. 6A, but hardly exerted an influence on the relationship shown, because the points for these 5 cohorts were all situ- ated within the cluster of points near the origin in Fig. 6A.

The production-per-recruit values for the 14 cohorts in which we studied growth rates in their 2nd growing season showed a significant increase with mean individual weight increments in this season (Fig. 8). Thus, the between-cohort variability in production per recruit shown by the solid points in Fig. 6B will have been due largely to variability in growth rates between cohorts. These growth rates were significantly related to cohort strength only if the largest cohort was included (as shown in Fig. 4B).

Elevated mortality is another factor that might have contributed to the reduced production at very high densities. However, we did not find any evidence for such an influence. At the end of the 2nd growing season an average ( $\mathrm{n}=5$ sites) of $60.4 \pm 4.2 \%$ of the cockles of the large 2011-cohort that were present at the start of the season were still alive. The proportion surviving their 2nd growing season was on average $(n=5$ : same sites) $60.0 \pm 4.9 \%$ for the 13 other cohorts we studied in detail. A comparison of mean growing-season mortality rates observed in all 14 years separately did not reveal any relationship with numerical densities at the start of the growing season $(\mathrm{r}=0.1, \mathrm{n}=14, \mathrm{p}=0.6)$. For the 1st full year following the end of the 2nd growing season, survival of the 2011 cohort amounted to $35 \pm 11 \%$ versus $46 \pm 8 \%$ for the other 13 cohorts $(n=5$, difference nonsignificant, $t$-test). Thus, the disappointing production realized by the exceptionally strong cohort of 2011 cannot be attributed to reduced survival.

A substantial influence of enhanced mortality on production was demonstrable in some other cohorts, namely those struck by heavy mortality as a consequence of low winter temperatures. Such serious mortality may continue after the sampling in March. As a consequence, production in a growing season immediately following a severe winter may be lower than expected on the basis of densities assessed in March. Moreover, numbers in such cohorts were very low at the start of subsequent growing seasons, resulting in negligible production in later years and lifetime perrecruit production values being roughly half of that in other cohorts (compare open and solid points in Fig. 6B). 

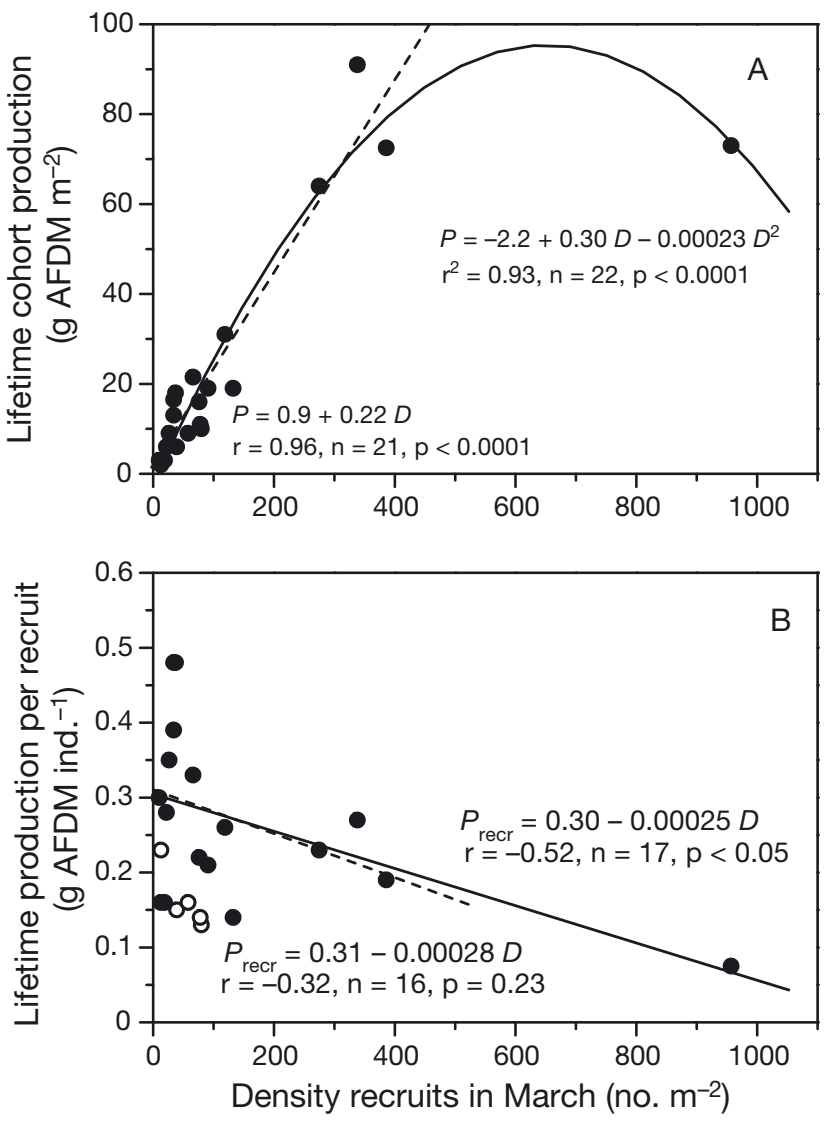

Fig. 6. Relationships between initial numerical densities $(D$, 10-mo-old recruits in no. $\mathrm{m}^{-2}$ ) and characteristics of lifetime somatic production $\left(P\right.$, in g AFDM m $\left.{ }^{-2}\right)$ of 22 cockle Cerastoderma edule cohorts in the central part of Balgzand (means of 6 sampling sites). Data on weak cohorts (initial density $<10 \mathrm{~m}^{-2}$ ) were omitted. (A) Initial density of cohorts (no. $\mathrm{m}^{-2}$ of recruits in March) and their subsequent lifetime production. (B) Initial density of cohorts (no. $\mathrm{m}^{-2}$ of recruits in March) and lifetime production per recruit $\left(P_{\text {recr }}\right)$ after March. Open points refer to the 5 cohorts that were struck by severe winter mortality early in life. Solid lines are best fits of all data; dashed lines are relationships for all years except the one with the highest initial cockle numbers. The solid line in (A) is a 2nd-order polynomial. The lines in (B) refer only to cohorts that were not struck by a severe winter

\section{DISCUSSION}

\section{Growth}

We found some evidence for negatively densitydependent growth in cockles, but this was significant only above infrequently occurring high densities of $>400 \mathrm{~m}^{-2}$ in cockles of $>10$ mo old. The statistical significance of the negative relationship between density and seasonal growth was fully due to the single (out of 14) cohort that was extremely strong, mem-

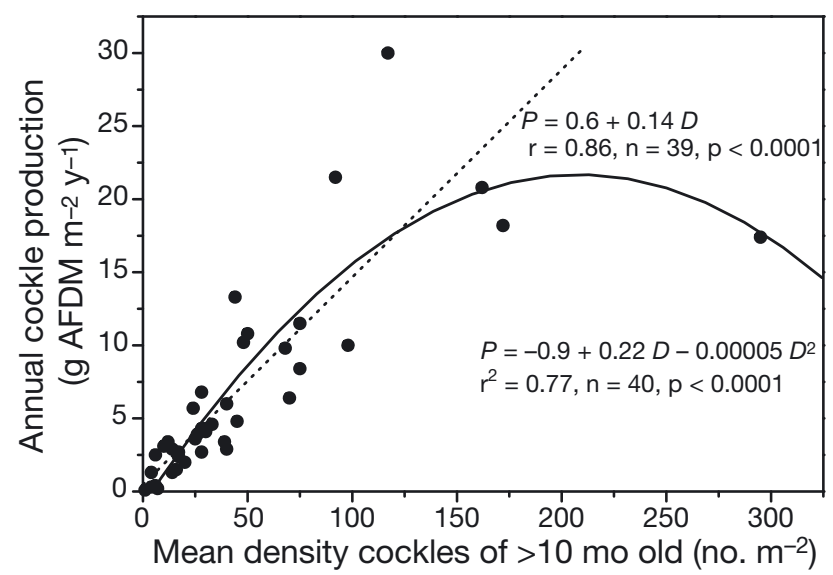

Fig. 7. Relationship between density of all cockles (Cerastoderma edule) present (except new recruits appearing in the course of the year) and total net annual (March-March) production on the entire Balgzand tidal-flat area (means of estimates at 15 sites). The solid line is a 2 nd-order polynomial fit for all data (40 annual estimates); the dashed line is a linear relationship for all years except the one with the highest cockle numbers

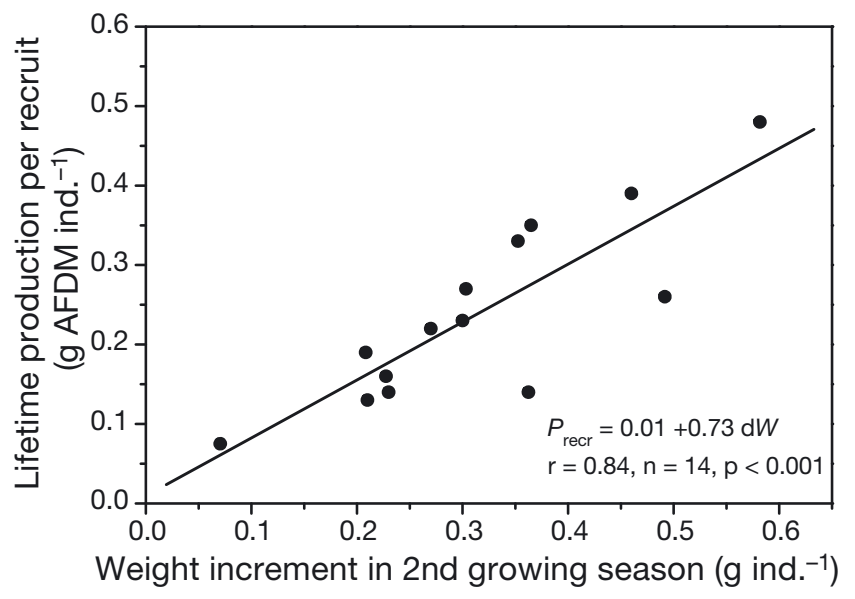

Fig. 8. Relationship in 14 cockle Cerastoderma edule cohorts between lifetime production per 10-mo-old recruit $\left(P_{\text {recr }}\right.$ in $g$ AFDM ind. ${ }^{-1}$ ) and the growth rate in the 2nd growing season of their life ( $\mathrm{d} W$ in $\mathrm{g}$ AFDM ind. $\left.{ }^{-1}\right)$. Data are means for the 6 sites in the central part of Balgzand and for cohorts that were sufficiently abundant in this area to allow a precise determination of weight increments. The strong 2011 cohort is represented by the leftmost point

bers of which showed seriously reduced growth rates. At the high density of $>600$ cockles $\mathrm{m}^{-2}$, individual weight increments were reduced by approximately 80 and $90 \%$ as compared to mean values in years with lower densities. The occurrence of such high cockle densities over extensive areas $\left(>10 \mathrm{~km}^{2}\right)$ appears to be a rare phenomenon. These high den- 
sities originate from highly successful recruitments (due to low epibenthic predator abundance; Beukema \& Dekker 2014). In cockles on Balgzand, we observed a recruitment success as high as in the 2011 year class only once in a $>40$-yr monitoring period. In other bivalve species on Balgzand, highly successful recruitments were also rare (Beukema et al. 2010, Beukema \& Dekker 2014). That is why it is inevitable that some far-reaching conclusions from studies such as the present one are based only on single data points referring to consequences of a rare event. Of course, the limitation of the approach of the present study is that some unknown environmental factor (not related to high cockle abundance) happened to be abnormal in 2012 and contributed significantly to the observed reduction of cockle growth in that year. In our opinion, it is not really an option to wait perhaps another $40 \mathrm{yr}$ to study cockle growth at an extremely high density for a second time and check our present conclusions.

Stronger reductions in cockle weights at even higher densities were observed by Jensen (1993) in the Danish Wadden Sea, with a reduction by $93 \%$ as compared to a year with low numbers (20 adult cockles $\mathrm{m}^{-2}$ compared with 2900-4000 adult cockles $\mathrm{m}^{-2}$ in the extremely strong cohort). The densities found by Jensen (1993) were higher than those recorded in the western Wadden Sea. For easy comparison, we included the weight observations by Jensen (1993) in Fig. 2 (triangular points). Further reports on growth retardation at high densities in cockles appear to be scarce. Hancock (1973) showed reduced length growth at local densities of $>1000$ cockles $\mathrm{m}^{-2}$ in England. In an adaptation of data on cockle lengths collected in the 1930s by Kreger (1940) in the Dutch Wadden Sea, Peterson \& Black (1987) showed reduced length growth at all densities $>200$ cockles $\mathrm{m}^{-2}$. Similar field observations in other bivalve species, with growth reductions observed exclusively at very high numerical densities, were reported by Peterson \& Black (1993) in 2 Katelysia species in Australia, and by Weinberg (1998) in Spisula solidissima in the USA. In suspension-feeding bivalves, intraspecific competition for resources appears to be generally weak as long as numbers are not extremely high.

The prime limiting resource in competition leading to reduced growth in this population of cockles is food shortage. The availability of suspended algae is affected by the abundance of all filter feeders. On Balgzand, years with high filter-feeder biomass are characterized by dominance of cockles (see Fig. 2 of Beukema et al. 2010). Intra-specific competition for food between cockles, therefore, will play a main role in competition for suspended algae in the total bivalve community in years with large bivalve stocks. Some evidence is present for such inter-specific competition. Kamermans (1993) found strong relationships between cockle growth and phytoplankton concentrations in the overlying water and in the stomachs of cockles. Food concentrations rapidly decline when water passes beds of filter feeders of the same or other species, such as mussels Mytilus edulis (Wright et al. 1982, Dame \& Dankers 1988, Asmus \& Asmus 1991), and cockle growth has been found to be reduced in places close to mussel beds (Kamermans 1993).

Part of the cockle population in the Wadden Sea lives in extensive beds, and these cockles will suffer from food depletion in the overlying and passing water by activities of their neighbors (Peterson \& Black 1987). From the relationships we observed between density and growth, it may be concluded that, up to a certain bed size and within-bed density, the competition for food was not significant and did not result in demonstrable growth reduction. The explanation will be that most of their food is not produced on the spot but is supplied in large amounts from elsewhere by sufficiently strong tidal currents (Loo \& Rosenberg 1996).

\section{Production}

Production was defined as biomass formation and its rates were estimated as weight-increment summation by multiplication of numerical densities and growth rates. Numbers of cockles were far more variable than their weight increments: the former varied from year to year over no less than 2 orders of magnitude, the latter by a factor of $\sim 10$. Magnitudes of annual production were largely determined by the contributions of single strong cohorts (Beukema \& Dekker 2006). Production of a cohort was determined primarily by its initial strength $\left(\mathrm{n} \mathrm{m}^{-2}\right.$ of 10 -mo-old recruits). Thus, as compared to the role of variation in recruitment, variability in rates of growth or mortality played only minor roles in determining production (and resulting biomass; Beukema et al. 2010). The influence of growth rate was substantial only in the case of the exceptionally strong cohort of 2011. The cockles belonging to this cohort showed seriously reduced growth rates, particularly in 2012, i.e. in their 2nd growing season. The lion's share of production by a cockle cohort is realized in its 2nd growing season. As a consequence, annual production was 
not exceptionally high in 2012, despite the exceptionally high numbers of adult cockles. In other cohorts, with lower initial densities, weight increments were not significantly related to density, and a possible negative density dependence of growth did not reduce production at high numbers.

Before the appearance of the exceptionally strong 2011 year class of cockles, cohort production in Wadden Sea populations of bivalves was thought to generally increase linearly with initial cohort strength (cockle C. edule, Beukema \& Dekker 2006; mussel Mytilus edulis, Beukema \& Dekker 2007; Macoma balthica, Van der Meer et al. 2001, Dekker \& Beukema 2007; Ensis directus, Dekker \& Beukema 2012). Apparently, in all cohorts of these species, intra-specific competition was always so weak as to prevent a consistent growth-rate reduction at higher numbers that would decrease production at high numerical densities and reduce production per recruit to a relatively low value. Over a broad range of numerical densities, annual cockle production in the Balgzand area increased with density (Fig. 7) to reach maximal production rates at 100 to 200 cockles $\mathrm{m}^{-2}$. These densities are averages of all cockles present (except youngof-the year in summer) over the entire $50 \mathrm{~km}^{2}$ tidal-flat area. Substantial parts of this area, however, were unsuitable for cockles because of their intertidal height or sediment composition (Beukema \& Dekker 2009). In the most suitable, central part of Balgzand (comprising less than half of the total 50$\mathrm{km}^{2}$ tidal-flat area), maximal production rates were realized at optimal densities of $\sim 500$ cockles $\mathrm{m}^{-2}$ at the start of the growing season (Fig. 6A).

Demonstrable reductions of rates of weight increment and of production per recruit by negative density dependence appear to be rare in bivalve populations in the Wadden Sea. In our monitoring study, the case of the 2011 cockle cohort was unique among production estimates for 20 to 30 cohorts in each of 4 species, with a total of $\sim 100$ lifetime production estimates in bivalve year classes. In all of these cases, with the exception of this one cockle cohort, we did not observe any significant growth reduction at high numbers. If carrying capacity of an area is defined as the consumer abundance at which their growth becomes significantly reduced, the conclusion may be warranted that the carrying capacity of the western Wadden Sea for bivalves has rarely been reached during recent decades.

Armonies \& Reise (2003) concluded that macrozoobenthic species usually do not occupy the full range of suitable habitat, leaving a lot of empty space unoccupied, probably as a consequence of failing recruitment. Reise (1985) suggested that tidal-flat and similar benthic ecosystems are functioning in most years well below their carrying capacity for bivalves. We agree with these ideas that, generally, population size in bivalves and other coastal marine benthic species might be regulated primarily in a top-down way (by predation on early benthic stages; Beukema \& Dekker 2014) rather than by a bottom-up process by limited food resources. As a relatively eutrophic and productive area with high levels of primary production and chlorophyll concentrations ever since the late 1970s (Philippart et al. 2007), the Wadden Sea at present will have a high carrying capacity.

Acknowledgements. We are grateful to Jaap van der Meer (NIOZ, Texel) and 2 anonymous reviewers for their constructive comments.

\section{LITERATURE CITED}

Armonies W, Reise K (2003) Empty habitat in coastal sediments for populations of macrozoobenthos. Helgol Mar Res 56:279-287

Asmus RM, Asmus H (1991) Mussel beds: limiting or promoting phytoplankton? J Exp Mar Biol Ecol 148:215-232

Beukema JJ (1989) Bias in estimates of maximum life span, with an example of the edible cockle, Cerastoderma edule. Neth J Zool 39:79-85

Beukema JJ, Cadée GC (1997) Local differences on macrozoobenthic response to enhanced food supply caused by mild eutrophication in a Wadden Sea area: food is only locally a limiting factor. Limnol Oceanogr 42:1424-1435

> Beukema JJ, Dekker R (2005) Decline of recruitment success in cockles and other bivalves in the Wadden Sea: possible role of climate change, predation on postlarvae and fisheries. Mar Ecol Prog Ser 287:149-167

Beukema JJ, Dekker R (2006) Annual cockle Cerastoderma edule production in the Wadden Sea usually fails to sustain both wintering birds and a commercial fishery. Mar Ecol Prog Ser 309:189-204

Beukema JJ, Dekker R (2007) Variability in annual recruitment success as a determinant of long-term and largescale variation in annual production of intertidal Wadden Sea mussels (Mytilus edulis). Helgol Mar Res 61:71-86

Beukema JJ, Dekker R (2009) The intertidal zoning of cockles (Cerastoderma edule) in the Wadden Sea, or why cockle fishery disturbed areas of relatively high biodiversity. Helgol Mar Res 63:287-291

Beukema JJ, Dekker R (2014) Variability in predator abundance links winter temperatures and bivalve recruitment: correlative evidence from long-term data in a tidal flat. Mar Ecol Prog Ser 513:1-15

Beukema JJ, Cadée GC, Hummel H (1983) Differential variability in time and space of numbers in suspension and deposit feeding benthic species in a tidal flat area. Oceanol Acta Special Issue: 21-26

Beukema JJ, Dekker R, Essink K, Michaelis H (2001) Synchronized reproductive success of the main bivalve species in the Wadden Sea: causes and consequences. Mar Ecol Prog Ser 211:143-155 
Beukema JJ, Dekker R, Philippart CJM (2010) Long-term variability in bivalve recruitment, mortality, and growth and their contribution to fluctuations in food stocks of shellfish-eating birds. Mar Ecol Prog Ser 414:117-130

Dame RF, Dankers N (1988) Uptake and release of materials by a Wadden Sea mussel bed. J Exp Mar Biol Ecol 118: 207-216

de Montaudouin X, Bachelet G (1996) Experimental evidence of complex interactions between biotic and abiotic factors in the dynamics of an intertidal population of the bivalve Cerastoderma edule. Oceanol Acta 19:449-463

- Dekker R, Beukema JJ (2007) Long-term and large-scale variability in productivity of the tellinid bivalve Macoma balthica on Wadden Sea tidal flats. Mar Ecol Prog Ser 337:117-134

Dekker R, Beukema JJ (2012) Long-term dynamics and productivity of a successful invader: The first three decades of the bivalve Ensis directus in the western Wadden Sea. J Sea Res 71:31-40

Hancock DA (1973) The relationship between stock and recruitment in exploited invertebrates. Rapp P-V Réun Cons Int Explor Mer 164:113-131

> Jensen KT (1992) Dynamics and growth of the cockle, Cerastoderma edule, on an intertidal mud-flat in the Danish Wadden Sea: effects of submersion time and density. Neth J Sea Res 28:335-345

> Jensen KT (1993) Density-dependent growth in cockles (Cerastoderma edule): evidence from interannual comparisons. J Mar Biol Assoc UK 73:333-342

Kamermans P (1993) Food limitation in cockles (Cerastoderma edule (L.)): influences of location on tidal flat and of nearby presence of mussel beds. Neth J Sea Res 31: $71-81$

Kamermans P, Van der Veer HW, Karczmarski L, Doeglas GW (1992) Competition in deposit- and suspension-feeding bivalves: experiments in controlled outdoor environments. J Exp Mar Biol Ecol 162:113-135

Kreger D (1940) On the ecology of Cardium edule L. Arch

Editorial responsibility: Richard Osman, Edgewater, Maryland, USA
Neerl Zool 4:157-200

- Lammens JJ (1967) Growth and reproduction of a tidal flat population of Macoma balthica (L.). Neth J Sea Res 3: 315-382

> Levinton J (1972) Stability and trophic structure in depositfeeding and suspension-feeding communities. Am Nat 106:472-486

Loo LO, Rosenberg R (1996) Production and energy budget in marine suspension feeding populations: Mytilus edulis, Cerastoderma edule, Mya arenaria and Amphiura filiformis. J Sea Res 35:199-207

> Peterson CH, Black R (1987) Resource depletion by active suspension feeders on tidal flats: influence of local density and tidal elevation. Limnol Oceanogr 32:143-166

> Peterson CH, Black R (1993) Experimental tests of the advantages and disadvantages of high density for two coexisting cockles in a Southern Ocean lagoon. J Anim Ecol 62:614-633

Philippart CJM, Beukema JJ, Cadée GC, Dekker R and others (2007) Impacts of nutrient reduction on coastal communities. Ecosystems 10:96-116

Reise K (1985) Tidal flat ecology. An experimental approach to species interactions. Springer Verlag, Berlin

Van der Meer J, Beukema JJ, Dekker R (2001) Long-term variability in secondary production of an intertidal bivalve population is primarily a matter of recruitment variability. J Anim Ecol 70:159-169

Van der Meer J, Heip CH, Herman PJM, Moens T, Van Oevelen D (2005) Measuring the flow of energy and matter in marine benthic animal populations. In: Eleftheriou A, McIntyre A (eds) Methods for the study of marine benthos, 3rd edn. Blackwell Science, Oxford, p 326-407

- Weinberg JR (1998) Density-dependent growth in the Atlantic surfclam, Spisula solidissima, off the coast of the Delmarva Peninsula, USA. Mar Biol 130:621-630

> Wright RT, Coffin RB, Ersing CP, Pearson D (1982) Field and laboratory measurements of bivalve filtration of natural marine bacterioplankton. Limnol Oceanogr 27:91-98

Submitted: May 21, 2015; Accepted: September 15, 2015 Proofs received from author(s): October 21, 2015 